\title{
Artelogie
}

Recherche sur les arts, le patrimoine et la littérature de l'Amérique latine

$7 \mid 2015$

Photographie contemporaine en Amérique latine

\section{Quadros de uma exposição: um retrato do Brasil oitocentista na coleção Francisco Rodrigues (1840-1920)}

Ana Maria Mauad

\section{(2) OpenEdition}

\section{Journals}

\section{Edição electrónica}

URL: https://journals.openedition.org/artelogie/1119

DOI: 10.4000/artelogie.1119

ISSN: 2115-6395

Editora

Association ESCAL

Refêrencia eletrónica

Ana Maria Mauad, «Quadros de uma exposição: um retrato do Brasil oitocentista na coleção Francisco Rodrigues (1840-1920)», Artelogie [Online], 7 | 2015, posto online no dia 15 abril 2015, consultado o 11 abril 2022. URL: http://journals.openedition.org/artelogie/1119 ; DOI: https://doi.org/ 10.4000/artelogie.1119

Este documento foi criado de forma automática no dia 11 abril 2022.

Association ESCAL 


\title{
Quadros de uma exposição: um retrato do Brasil oitocentista na coleção Francisco Rodrigues (1840-1920)
}

\author{
Ana Maria Mauad
}

1 Em 2011, no âmbito do festival anual de fotografia FotoRio, coordenado pelo fotógrafo e antropólogo Milton Guran, foi apresentada, no Museu Nacional de Belas Artes do Rio de Janeiro, uma exposição de fotografias composta a partir da Coleção Francisco Rodrigues (CFR), cujo valioso acervo está depositado no Centro de Documentação e de Estudos da História Brasileira (Cehibra), da Fundação Joaquim Nabuco, situada na cidade de Recife, em Pernambuco. A curadoria da exposição ficou sob a minha responsabilidade e de Milton Guran, com apoio da equipe de pesquisadores do Centro de Documentação da Fundação.

2 A Coleção Francisco Rodrigues 1840-1920 é uma das mais importantes coleções fotográficas na esfera dos estudos sobre história das imagens e do seu papel na compreensão das relações sociais no Brasil do final do final do século XIX e início do XX. Neste sentido, a possibilidade de organizar uma exposição da grandeza do FotoRio 2011, um importante evento internacional de fotografia no Brasil, e, justamente, no espaço no Museu Nacional de Belas Artes, no Rio de Janeiro, valorizaria a fotografia tanto como expressão artística quanto importante suporte de relações sociais, que se tornam visíveis por meio das imagens técnicas.

3 No conjunto escolhido para compor a exposição intitulada Um retrato da sociedade brasileira - A Coleção Francisco Rodrigues 1840 -1920, buscou-se revelar, por um lado, aspectos da riqueza de técnicas e processos propriamente fotográficos, dentre os quais : daguerreótipos, ambrótipos, ferrótipos e, inclusive, um raro exemplar de talbótipo (calótipo), processos fotográficos próprios do século XIX, que são complementados pelos modelos carte-de-visite e cabinet size, mais populares na época; bem como os formatos próprios ao início do século $\mathrm{XX}$, os cartões postais. Por outro lado, objetivou- 
se compor um retrato das relações de gênero, raça, classe e geração que orientaram as práticas sociais no Brasil desse período e que ganham a cena pública por meio do suporte fotográfico.

4 Nesse sentido, a exposição Um retrato da sociedade brasileira - A Coleção Francisco Rodrigues 1840 -1920, permitiu uma leitura das diferenças sociais e processos de construção de identidades que definiram a imagem e autoimagem do Brasil Imperial e no início da República, ao mesmo tempo em que, revelaria que colecionar é também construir monumentos para o futuro.

O que se propõe nesse artigo é tomar essa experiência como objeto de reflexão, considerando-se os usos e funções da fotografia, quando parte de uma coleção, e a curadoria como forma de produzir narrativas históricas, voltadas para novos públicos que buscam conhecer o passado por meio das imagens fotográficas.

\section{Opulência e distinção social nas fotografias da coleção Francisco Rodrigues}

6 A coleção é fruto do trabalho do cirurgiã-dentista Francisco Rodrigues (1904-1977) que deu continuidade a iniciativa de seu pai, Augusto Rodrigues, que se dedicara a formar uma galeria de notáveis figuras do Oitocentos. Francisco Rodrigues ampliou imensamente o que foi iniciado pelo pai, revelando-se um colecionador com sensibilidade suficiente para fornecer à Coleção um rosto histórico e social da diversidade social brasileira. $\mathrm{O}$ excepcional conjunto da Coleção Francisco Rodrigues reúne mais de 17 mil fotografias assinadas por importantes fotógrafos que atuaram no Brasil e no exterior nos séculos XIX e XX, compondo um perfil diverso e variado da vida social brasileira, aberta à consulta pública no Portal Domínio Público do MEC.

7 Originária do extinto Museu do Açúcar, vinculado ao Instituto do Álcool e do Açúcar IAA, e incorporada ao acervo da Diretoria de Documentação da Fundação Joaquim Nabuco em 1974, a Coleção Francisco Rodrigues de Fotografias (1840-1920) compõe um conjunto de fotografias no qual se revela os usos da imagem tanto como representação da autoimagem das camadas dominantes, quanto marcadores de diferenças entre grupos sociais que compunham a sociedade da atual região Nordeste, no século XIX até as primeiras décadas do XX, de base escravista.

8 Na Coleção, encontram-se documentadas várias faces da vida social e cultural brasileira em um período rico de transformações econômicas, políticas, sociais, culturais e tecnológicas, com predomínio dos retratos de família, especialmente das famílias das classes sociais dominantes como senhores de engenhos, usineiros, representante da burguesia urbana e camadas médias da população, além de conter registros fotográficos de segmentos e grupos sociais a elas associados, incluindo imagens raras de escravos domésticos e de amas de leite.

Um outro aspecto a ser destacado, o das valiosas informações que a Coleção expressa e veicula, sobre as mudanças advindas nos processos tecnológicos, ocorridas ao longo da história da fotografia, desde a primeira metade do século XIX às décadas iniciais do XX. Traz exemplares em daguerreótipos, ambrótipos, talbótipos e em diversas formas de impressão em papel : albumina, papel salgado, fotopintura, cianotipia, platinotipia.

10 Na Coleção Francisco Rodrigues destaca-se de seu conjunto diferentes modalidades de retratos. Nessas representações figuram casais bem vestidos; famílias devidamente 
organizadas em torno do pai de família; homens e mulheres de diferentes idades e classe, com detalhe no rosto ou na composição de corpo inteiro; grupos, homens, mulheres ou ainda mistos fazendo pose e encenando situações variadas; ou finalmente crianças sozinhas ou acompanhadas de adultos, em geral, a mãe ou a ama. Nesses retratos se revela um mundo de objetos interiores, dentre mobiliário, adereços e acessórios que servem de base à ambientação ilusória do estúdio e se apresentam associados a um conjunto objetos pessoais - vestidos de modelos, joias, ternos bem cortados, véus, pentes de cabelo, brincos, bem como fantasias e roupas infantis - para composição das referências de opulência e distinção social próprios à construção de uma identidade de classe, gênero e geração para o espaço social regional.

11 A noção de opulência ligada ao Nordeste brasileiro provém do período colonial e do nível de riqueza gerada pela sociedade açucareira. ${ }^{1}$ No século XIX, os padrões de fortuna não se mediam mais pela abundância e prodigalidade próprias ao cotidiano das grandes fazendas de açúcar do Nordeste colonial, o que vale neste momento é a ostentação do consumo de luxo e da frequência a lugares exclusivos, medida inclusive pelo consumo de imagens de fotógrafos notáveis. A opulência da sociedade tem como fiel da balança social as estratégias de distinção, da qual o retrato fotográfico é o seu melhor índice.

12 A literatura, sobre o retrato fotográfico, aponta que este não pode prescindir de um conjunto de condições que determinam um campo próprio no âmbito da representação da figura humana. Segundo Fabris, as condições apresentadas pelos estudiosos do formato,

Podem ser enfeixadas no conceito de individualização, do qual deriva um código de representação particular, que inclui três elementos: pose, enquadramento artificial, primazia do rosto em relação ao restante do corpo. 0 retrato fotográfico herda do retrato pictórico a preocupação com o modelo luminoso e com a tradução do relevo espacial, o que lhe permite condensar numa única imagem os traços distintivos da fisionomia e os atributos sociais da personalidade. Aos atributos herdados, o retrato fotográfico acrescenta alguns elementos que deveriam distingui-lo do modelo anterior - fidelidade à imagem real, capacidade de comprovação e ilusão mimética-, dificilmente localizáveis nas composições idealizadas da pintura (Fabris, 2009:45)

13 A autora apoia-se nas considerações de Roland Barthes, em "Câmara Clara", ao afirmar que o retrato fotográfico é resultado de um jogo de espelhos que envolvem "quatro personas: "Aquele que o retratado acredita ser; aquele que ele gostaria que os outros vissem nele; aquele que o fotógrafo acredita que ele seja ; aquele que o fotógrafo se serve para exibir sua arte". (Idem : 46)

Nesse jogo de papéis sociais refletidos, o retrato fotográfico dentro do circuito social da imagem oitocentista, nos formatos que se apresentavam - carte de visite e cabinet size, atuavam como um poderoso dispositivo social. Um artefato de submissão do sujeito histórico às normas e valores morais de sua época. O que a produção do retrato fotográfico, compreendida como a negociação da pose entre fotógrafo e modelo, revela é um duplo movimento de sujeição e imposição. Do lado do fotógrafo, observa-se a sujeição às normas do bom gosto e da harmonia para a composição estética perfeita de um 'bom retrato' ; e do sujeito-fotografado a imposição de normas de distinção social quer seja de classe, de gênero ou de geração. Assim, o modelo ao negociar a sua pose com o fotógrafo, coloca em jogo a sua autoimagem, desse modo, como ele projeta no seu corpo as expectativas do mundo do qual é parte integrante. 
15 A pose orienta a encenação de personagens que assumem máscaras sociais, tanto mais evidentes quanto mais abundantes são os objetos interiores e pessoais que compunham a mise en scène fotográfica. Entretanto, com a aceleração do tempo de tomada da imagem fotográfica, estabeleceu-se entre o fotógrafo e seu fotografado uma negociação para se chegar a um consenso sobre o que deveria ser mostrado e como, segundo Mauricio Lissovsky : "O estúdio do retratista das últimas décadas do século XIX reflete esse desaparecimento da duração, colocando à disposição de ambos um arsenal de elementos (peças de mobiliário e decoração, fundos pintados etc.), que deviam ser arranjados segundo um acordo prévio. 0 tempo que se desprende entre eles, agora, é o de uma negociação em torno da imagem. Não é mais um intervalo por onde uma experiência se infiltra, mas o transcurso necessário à conformação de um contrato". (Lissovsky, 2005 : 201)

16 A escolha de objetos interiores e pessoais para a composição aponta para a universalização dos códigos de representação burgueses pelo retrato fotográfico. Assim, os mesmos objetos que serviam de apoio à composição do retrato fotográfico em Londres, Paris ou Nova York, poderiam ser encontrados nos estúdios brasileiros, compondo o imaginário burguês urbano com o qual o sujeito moderno gostaria de se ver integrado. No Rio de Janeiro oitocentista, os estúdios fotográficos destacavam a riqueza do arranjo dos seus 'salões de pose' e as lojas que se especializaram na venda de materiais fotográficos colocavam em destaque a existência acessórios próprios ao retrato, tais como: cortinados, fundos pintados, colunas, e até mesmo peças do mobiliário para o benefício dos fotógrafos profissionais. Vale apontar que "a única contribuição brasileira para esse repertório é a utilização de cercas rústicas de madeira, mais comuns entre os fotógrafos da Bahia e de Pernambuco." (idem)

É interessante refletir sobre a experiência histórica que fundamenta a prática fotográfica, notadamente, a do retrato na modalidade carte de visite. Poses que se repetem, repertórios de objetos que se duplicam, prescrições rígidas de fotógrafos em relação à pose, normas convencionalizadas para a composição estética do retrato, negociações entre fotógrafo e modelo para um resultado aceitável por ambos, enfim, o que tudo isso revela sobre a sociedade que produz e consome essas imagens? Ainda, seguindo as ponderações de Lissovsky, o carte de visite, muito mais do que um formato ou uma tecnologia, deve ser considerado como um 'dispositivo' fotográfico complexo, cuja análise permite dar uma resposta mesmo que parcial a questão levantada:

Patenteado por Disderi em 1855, barateou enormemente o custo do retrato, tornando-se a forma favorita de personalizar os cidadãos burgueses em meio a um ambiente que lhes valorizava a figura e a posição social. Além do custo relativamente baixo e de seu caráter múltiplo, que permitia a distribuição de cópias dos retratos entre parentes e conhecidos, o dispositivo do carte de visite possuía uma outra característica fundamental e inovadora. Ele induzia à coleção por meio de álbuns dotados de cantoneiras no tamanho exato dos cartões que serviam de suporte às imagens. Nesses álbuns, as famílias colecionavam, além das efígies dos seus membros, retratos de amigos, da família imperial, de personalidades nacionais e estrangeiras, inclusive artistas e atores de teatro[...] o álbum de carte de visite formava uma espécie de comunidade 'democrática' do visível que, ao mesmo tempo em que nivelava a todos, emprestava a cada um a dignidade que emanava de seus vizinhos de página [...]Reunidos em álbuns, os carte de visite são a manifestação de uma utopia caracteristicamente moderna. Em face de uma experiência cotidiana cada vez mais fragmentada e acelerada, onde pertencimentos tradicionais começam a esmaecer-se, o pequeno-burguês do século XIX reconfortava-se com o seu Novo Mundo de imagens, cuja estabilidade era garantida pela existência de outras 
coleções das quais ele estaria presumivelmente ausente (os retratos licenciosos, as fotografias de identificação criminal, de tipos 'estrangeiros' e de insanos). 0 álbum de retratos consubstanciava o sonho de que, em alguma instância, as características e talentos individuais dos homens notáveis, por mais disparatados que fossem, reuniam-se numa 'comunidade de semelhantes', cuja existência virtual assegurava a possibilidade do 'progresso social (Idem : 201, 2015-206)

Assim sendo, no momento da sua produção, o retrato integrava uma economia visual que garantia ao sujeito histórico tanto, a adequação a uma norma moral, que lhes conferia identidade de grupo ; quanto, a aferição de uma alteridade de classe pela delimitação de uma pose subalterna na representação do grupo dominante. Neste caso, se incluem os retratos de escravos ou ex-escravos incorporando a máscara social do patrão, pela imposição da mise en scène do retrato de estúdio, com todos os objetos interiores e pessoais pertencentes ao mundo dos ricos e poderosos, ou ainda, quando foram retratados evidenciando a sua condição servil.

Entretanto, como compreender essas imagens, sobretudo os retratos fotográficos, quando elas passam a integrar uma coleção?

\section{Coleções em perspectiva comparada}

20 Algumas hipóteses podem ser levantadas, para responder a indagação acima feita, em certa medida, associadas às condições históricas nas quais se desenvolveram as práticas fotográficas promovidas pela constituição estados nacionais e suas comunidades de sentido (Baczko, 1985)

21 Uma breve mirada em perspectiva comparada para a produção recente nos programas de pós-graduação em História, serve de balão de ensaio para futuros estudos sobre como se formaram, no Brasil, as coleções de retratos fotográficos, de vistas e paisagens e de séries documentais, relacionadas à emergência e consolidação da fotografia pública no século XX (Mauad, 2013). O exercício inicial permite compor uma tipologia de acervos relacionada aos circuitos sociais da fotografia, em que se identifica, em primeiro lugar, coleções de retratos provenientes do trabalho de fotógrafos imigrantes. Fotógrafos que se deslocaram de seus países de origem em situações de conflito e crise, notadamente na primeira metade do século XX, imigrando para regiões específicas do Brasil e aí estabelecendo um negócio fotográfico. Esse fenômeno evidencia-se em pesquisas históricas que investiram na descoberta, no tratamento, na organização e, sobretudo, na valorização histórica de coleções de acervos de estúdios fotográficos de imigrantes, notadamente alemães, em regiões de fronteira no Rio Grande do Sul e no Paraná.

22 Nesse primeira categoria incluem-se teses e dissertações que aportam pesquisa original sobre o tema, dentre as quais destacam-se, por caracterizam o fenômeno de forma exemplar, os trabalhos de Teresinha Gregory (2010), Ivo Canabarro (2011), Anthony Beux Tessari (2013) e de Carmem Ribeiro (2014)

23 Um segundo tipo de coleção de fotografias que incluem o retrato fotográfico, entre outros tipos de imagem, resulta da atuação de fotógrafos, na sua maioria de procedência estrangeira, que imigraram para o Brasil em meados do século XX, trazendo na sua bagagem uma expertise fotográfica que que orientou a sua trajetória. Nesse caso, o destino dos fotógrafos foram as regióes industrializadas e urbanizadas, em que poderiam oferecer serviços fotográficos diversos e multiplicar o potencial criativo 
da prática fotográfica em fotografias de publicidade, de imprensa, ou ainda, comissionadas pelo Estado. As coleções fotográficas provenientes desse segundo tipo de prática, encontram-se valorizadas por seus proprietários, tornando-se cada vez mais, a base do agenciamento da fotografia como mercadoria, em que o valor agregado é atribuído pela raridade histórica, pela acuidade estética, ou ainda, pela trajetória do próprio fotógrafo pelos mundos da arte e/ou da política.

Os exemplos de coleções dentro dessa segunda categoria são muitos e estão distribuídos por arquivos públicos e institutos culturais, mas à titulo de referência registra-se a trajetória de duas coleções no Rio de Janeiro - Mario Baldi, estudada por Marcos de Brum Lopes (2013) e Kurt Klagsbrunn (2013), estudada por Mauricio Lissovsky ; em São Paulo a coleção da Fotolabor, fotografias de Werner Haberkorn, publicada em obra concebida por Bruna Callegari e Rafael Buosi (2014). Essas pesquisas recompõem a trajetória de fotógrafos imigrantes para regiões urbanizadas com propósitos profissionais voltados para uma prática fotográfica diversificada entre publicidade, etnografia, cobertura fotográfica, como também, retratos, que resultaram coleções com características comuns.

Um terceiro tipo de coleção resulta da prática fotográfica desenvolvida pelo fotojornalismo, principalmente, em revistas ilustradas e a partir dos anos 1950, nos jornais diários. Essas coleções, embora não incluam o retrato fotográfico em sentido clássico, permitem que se componha o perfil da população urbana das cidades, o mundo das celebridades, do poder e dos poderosos. Salvo raros acervos, como o do Correio da Manhã, sob a guarda do Arquivo Nacional, as fotografias da imprensa só podem ser acessadas pelos seus veículos de publicação nas hemerotecas públicas, como a da Biblioteca Nacional no Rio de Janeiro. Para essa terceira categoria destaca-se o estudo de Maria do Carmo Rainho (2014), que discute as expressões da moda no comportamento dos anos 1960, com base nas fotografias da coleção do Correio da Manhã e de Silvana Louzada (2013) que aborda a trajetória dos fotógrafos e da fotografia na cidade do Rio de Janeiro, com base no estudo de duas importantes coleções de jornais - Jornal do Brasil e Última Hora .

Por fim, a prática fotográfica desenvolvida nos foto clubes localizados nas principais capitais do Brasil desde as primeiras décadas do século XX, poderia ser considerada uma quarta categoria de coleção. Nesse âmbito, como no primeiro tipo, as pesquisas acadêmicas desenvolvidas nos programas de pós-graduação vêm contribuindo, sobremaneira, para mapear redes e a circulação de fotógrafos e fotografias entre o Brasil e o exterior, bem como identificar a experiência moderna na fotografia produzida no Brasil. Nessa categoria destacam-se, como precursores, os trabalhos de Maria Teresa Bandeira de Mello (1998), sobre o Foto Clube Brasileiro, no Rio de Janeiro ; de Helouise Costa (2004) sobre o Foto Cine Clube Bandeirantes, em São Paulo; o de Fabiana Bruce (2013) sobre o Foto Clube de Recife e Lucas Menezes (2013) sobre o Foto Clube de Belo Horizonte .

Nesse quatro casos, trata-se de delimitar o padrão da coleção pelo circuito social de sua produção, circulação e consumo, que se complementa pela forma como um conjunto de fotografias se torna uma coleção. Nesse caso, a coleção poderia ser pensada como um conjunto de fotografias em que a sua biografia lhe atribui uma identidade própria, quer seja pelo nome do fotógrafo, pela casa fotográfica ou ainda pela agência que a produziu. A trajetória desse conjunto pela história, a forma como ele se preserva, ou ainda, se amplia pela soma de novas imagens, é objeto de grande interesse para as pesquisas 
históricas atuais, por justamente evidenciar que a experiência fotográfica não está descolada da própria experiência histórica, em que se evidencia prática fotográfica na dimensão de relação social.

A coleção Francisco Rodrigues diferencia-se dos tipos apresentados, por se constituir pela vontade do colecionador em guardar certas fotografias da sociedade em que estava inserido - retratos fotográficos. Entretanto, sua excepcionalidade revela aspectos interessantes da própria biografia do colecionador e dos objetos de sua coleção.

\section{Colecionar para quê?}

"Eles (os retratos) estão dispersos...ameaçados de serem esquecidos, abandonados pela gente mais nova que não lhe dá valor...reunidos, vão contar muito melhor uma história" (argumento de Francisco Rodrigues para tentar obter de amigos e conhecidos os preciosos retratos que viriam compor sua coleção, depoimento de Silvia Rodrigues). (Funarte, $1983: 3$ )

O argumento apresentado por Francisco Rodrigues, mentor da coleção de fotografias, que acabou por ser batizada com seu próprio nome, revela uma importante pista sobre o significado de constituir uma coleção de fotografias, compor uma narrativa sobre o passado e despertar as gerações futuras para o valor histórico dessa comunidade de imagens. Entretanto, é interessante pensar o que leva um dentista a iniciar uma coleção de fotografias das mais diversas origens?

Evidencia-se, entre nos anos 1920 e 1930, a crescente preocupação com o debate sobre patrimônio histórico e a consequente formação de coleções associadas aos desígnios da construção da identidade nacional. Nesse ambiente, compreende-se a iniciativa de Francisco Rodrigues cuja coleção se forma ao longo do tempo, sendo o seu desejo mantido pelos descendentes e pelo próprio Estado, por meio da Fundação Joaquim Nabuco, que incorpora a guarda da coleção fazendo valer a vontade de seu fundador.

31 Annateresa Fabris ao considerar a fotografia como objeto de coleção reflete sobre as determinações objetivas e subjetivas que orientam o ato de colecionar:

Temática ou enciclopédica, a coleção fotográfica é uma abstração determinada pelo sujeito, que classifica, cataloga, ordena seus ícones, criando séries e seqüências que lhe permitem replasmar o mundo, forjar totalidades, cuja lógica é ao mesmo tempo pública e privada. Se, de um lado, o indivíduo elabora sua coleção a partir de um repertório em grande parte pré-constituído e que responde às questões culturais e científicas colocadas em pauta pelo momento histórico, há determinações próprias na base de cada conjunto, nas quais a ordem e a reunião convivem com o jogo e com a possibilidade da substituição indefinida. (Fabris, 2009:38)

32 Neste sentido, creio que vale a pena ir um pouco mais além, à compreensão dessa pulsão em dar sentido ao mundo pelos seus objetos. 0 escritor argentino Jorge Luis Borges, em seu conto "Funes, o memorioso" (Borges, 1979 : 477-484), relata a história de um homem que ao sofrer um acidente torna-se paraplégico. Preso, na sua condição de imobilidade, Funes desenvolve uma incrível capacidade de guardar informações na memória. Podia reconstruir todos os sonhos, todos os 'entre - sonhos'. Duas ou três vezes havia reconstruído um dia inteiro, não havia jamais duvidado, mas cada reconstrução havia requerido um dia inteiro. A essa capacidade de lembrar, Funes agregou outra, a de categorizar o que guardava na memória, criando assim novos nomes para as coisas que já haviam sido denominadas. 

Rodrigues de Fotografias 1840-1920, que se estende até o dia 17 de julho. A exposição apresenta uma mostra do rico acervo composto por 17 mil fotografias, preservadas no Centro de Estudos e de Documentação da História Brasileira da Diretoria de Documentação da Fundação Joaquim Nabuco, órgão do MEC sediado no Recife. Os curadores da exposição, Ana Maria Mauad, Universidade Federal Fluminense, Rita de Cássia Araújo, Fundação Joaquim Nabuco e Milton Guran, coordenador geral do FotoRio 2011, adotaram uma abordagem que valoriza tanto a diversidade das relações sociais que compõem o retrato do Brasil de meados do XIX até as primeiras décadas do XX, quanto os diferentes suportes e técnicas fotográficas, que incluem desde as mais antigas - daguerreótipos, ambrótipos, ferrótipos e talbótipo, passando pelos consagrados cartede-visite até as novidades do início do século XX, como a fotopintura, a cianotipia e o cartão postal. A exposição Um retrato da sociedade brasileira : Coleção Francisco Rodrigues de Fotografias 1840-1920, estrutura-se em diferentes ambientes, por meio dos quais se buscou apresentar a diversidade do acervo original. O percurso se inicia pela apresentação de um "mosaico das diversas formas de sociabilidade" ; em seguida, podem ser vistas imagens de notáveis com seus respectivos indicativos de riqueza e distinção social; há também ambientes dedicados à fotopintura, às fotografias de família e aos versos dos retratos, além de espaço para relíquias como daguerreótipos, ambrótipos e ferrótipos

Dentre as curiosidades da exposição, destacam-se fotos de gente famosa, como Carlos Gomes, Nabuco e Castro Alves, e de crianças mortas retratadas como se vivas 
estivessem - os chamados "anjinhos" e da presença negra no cotidiano social." (PressRelease, 9/06/2011)

Na síntese da proposta encaminhada para a divulgação na imprensa, para publicizar a exposição, destacamos a riqueza da coleção como contribuição para a história da fotografia, mas sobretudo para o papel da fotografia na elaboração de representações sociais, temática cara ao campo da história cultural. Em grande medida, buscamos valorizar na montagem da proposta expositiva o próprio agenciamento adotado por Francisco Rodrigues ao compor a sua coleção: diversidade de técnicas de retrato fotográfico aliada à multiplicidade de poses e trejeitos da sociedade que se apresentava por meio do registro fotográfico.

Em termos de projeto curatorial foi adotada a seguinte estratégia : pesquisa sistemática e minuciosa no banco de imagens da coleção para identificar os vários aspectos temáticos e os diversos processos fotográficos nela contidos; as imagens escolhidas foram agrupadas em núcleos de inteligibilidade, cada um acompanhado de um pequeno texto, de minha autoria, cuja função seria a de compor o fio condutor que orientaria o olhar do público, uma espécie de percurso conceitual que agregaria à fruição estética elementos de conhecimento. Não foram incluídas legendas para cada fotografia, priorizando-se a escolha de imagens da segunda metade do XIX e do mesmo formato (carte-de-visite e cabinet size) e processo (papel albuminado ou simplesmente albúmen). Além das fotografias expostas nas paredes, foram incorporadas vitrines para exibir estojos, álbuns e peças formatos muito pequenos, destacando o seu aspecto de "objeto precioso".

Utilizamos duas salas do Museu Nacional de Belas Artes situadas na Galeria das Esculturas, na parte lateral direita do Museu, partindo da sua entrada. Os originais dos retratos em papel foram exibidos com proteção de vidro antirreflexo encaixadas em painéis de papel cartão, cada um referente a um grupo dos núcleos temáticos que compuseram a narrativa da exposição. Já os álbuns e peças que compuseram o estúdio de "objetos preciosos", foram dispostos em uma outra sala, com a ambientação ilusória que aludia aos gabinetes de preciosidades oitocentistas. $O$ primeiro núcleo temático reuniu 14 quadros com em média três fotografias cada, em torno da noção de sociabilidades. Não foi colocado um título para os conjuntos, recorremos a esses conceitos chave para servir de referência interna da montagem. Acompanhava um texto de parede em que se anunciava:

Vários personagens, ambientes e situações compõem um mosaico de variadas formas de sociabilidade que se reformulam ao longo do período coberto pela coleção. Os rituais de passagem que reúnem os ciclos da vida e da constituição do grupo familiar ; as mise-enscènes e alegorias que denotam o valor da fotografia como encenação; os retratos de formatura que indicam o papel da educação formal na elaboração de padrão cultural letrado do grupo social dominante; os passeios, a vida ao ar livre, tudo isso permite entrever um pouco do vida cotidiana, nos dando um amplo panorama dos modos e costumes daquela época que surgem nessas imagens para nos impressionar e emocionar. 
1. Ginastas, c. 1889 , autoria não identificada

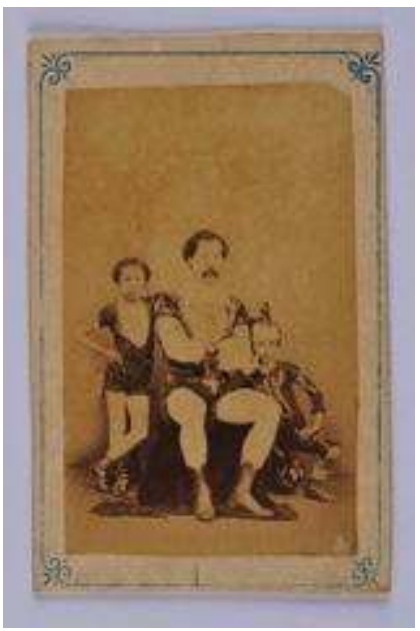

2. Militares, c. 1870 , Curitiba, J. Weiss \& CO

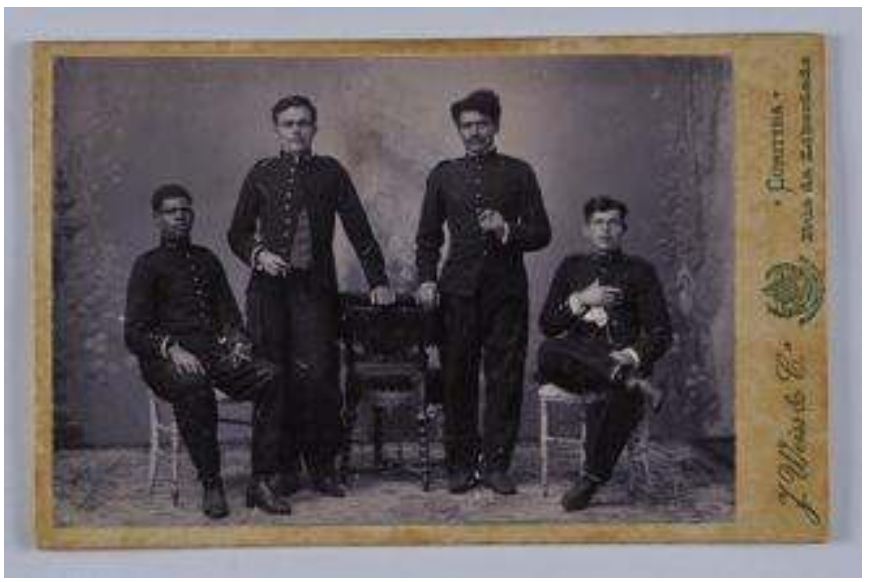

3. Anjinho, c. 1890 , Recife, autoria não identificada

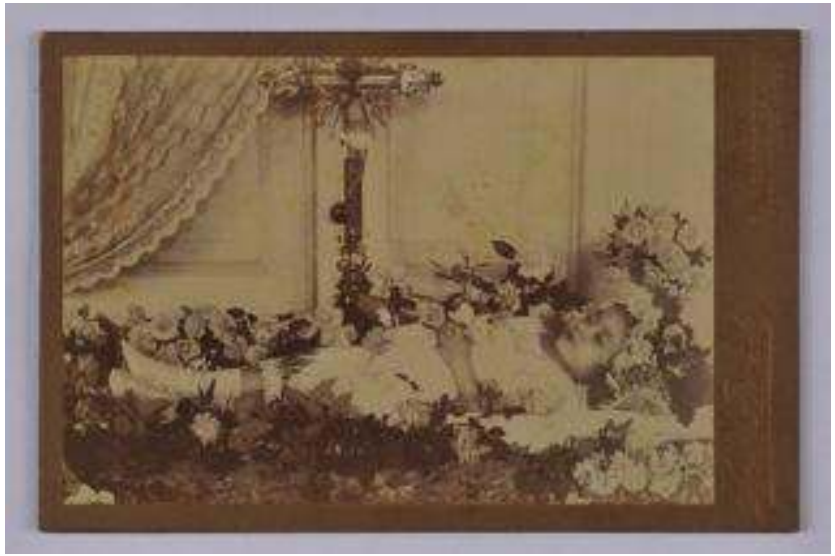


4. 1a Comunhão, Recife, autoria não identificada

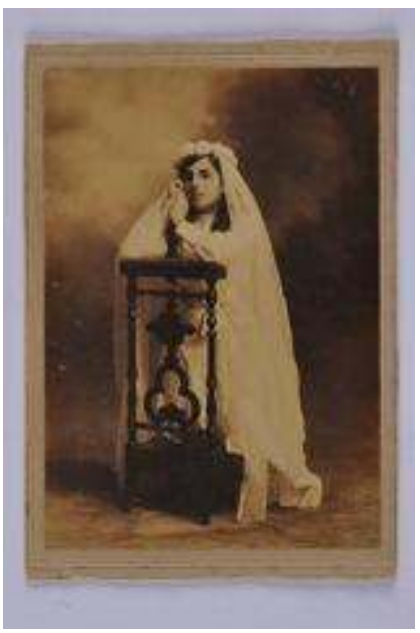

41 O segundo núcleo de inteligibilidade foi organizado em torno das categorias de gênero e distinção social, delineados no seguinte texto de apoio:

Nos primeiros momentos da fotografia, tão bem representados aqui, os retratos são indicativos da riqueza e da distinção social através da escolha da indumentária, das joias e também da estética facial, que podem funcionar como verdadeiras máscaras sociais. Paralelamente, se observa a gradual presença de indícios nos quais se evidencia a construção das identidades sociais por meio do retrato, numa dialética de representação de si e do outro. No século XIX as personalidades notáveis se retratavam tanto por meio da pintura, como pelo retrato fotográfico, símbolo da valorização da individualidade burguesa. É interessante notar que os retratos do tipo carte-de-visite (formato $6 \times 9 \mathrm{~cm}$ ) tinham a função semelhante as figurinhas dos álbuns de hoje em dia, pois serviam ao gosto popular de guardar a fotografia de quem admirava, ao mesmo tempo em que tornava pública a imagem que se queria ver preservada. Um verdadeiro monumento para políticos, letrados e artistas, ao gosto da nascente cultura do consumo. 
5. Carlos Gomes, c. 1860, Pará, Fidanza

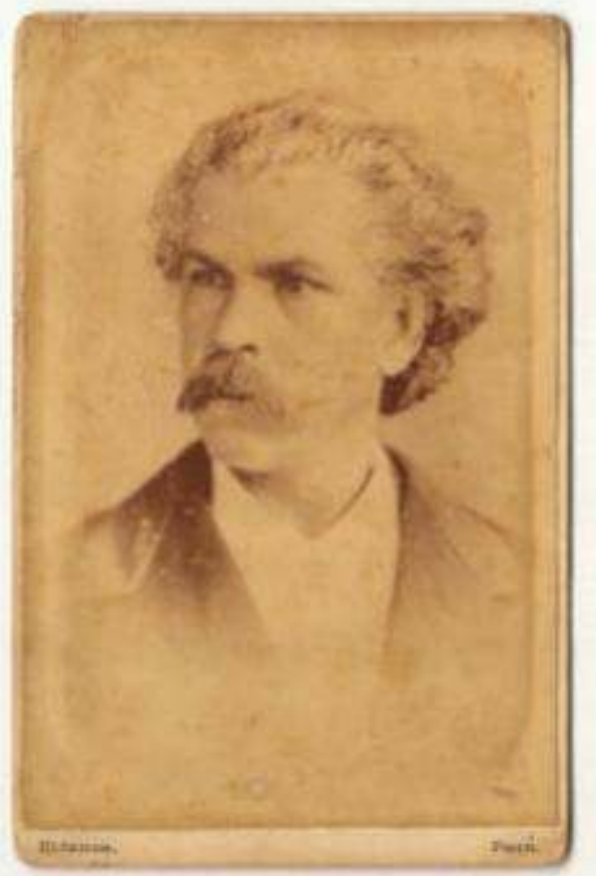

6. Liberto, c. 1870 , photographie Artistique, Pará

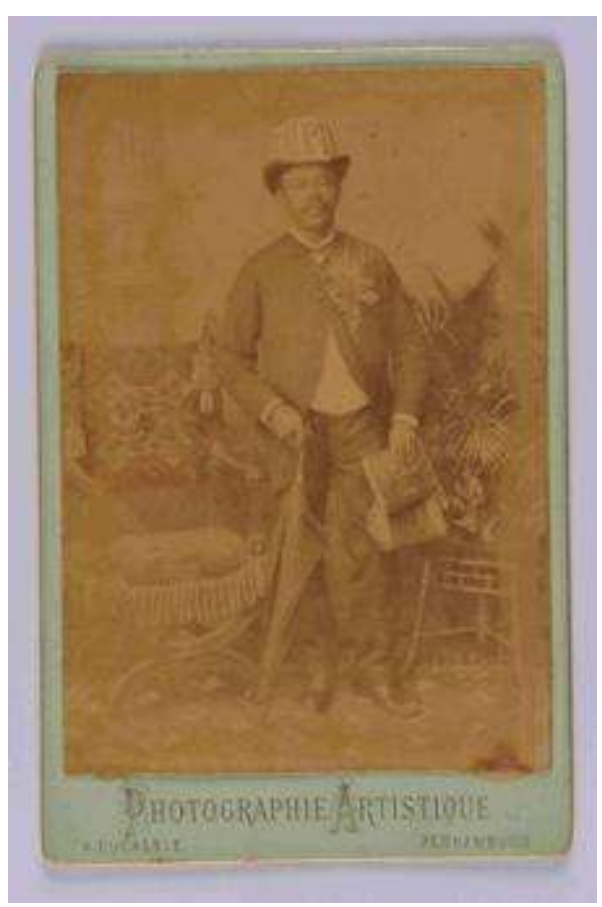


7. Retrato Feminino, c. 1890, PE, Louis Piereck

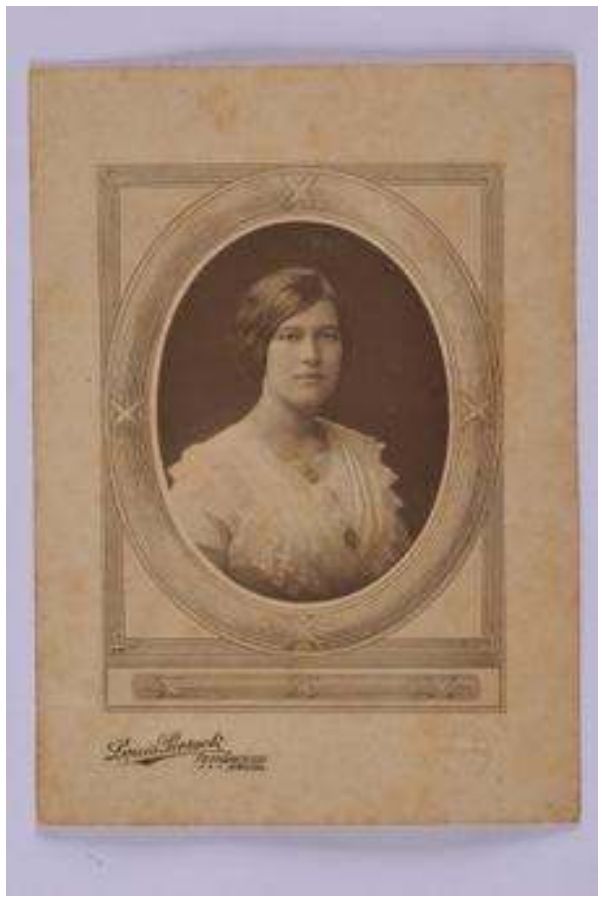

8. Retrato Feminino. C. 1880, PE, Alberto Henschel \& Co

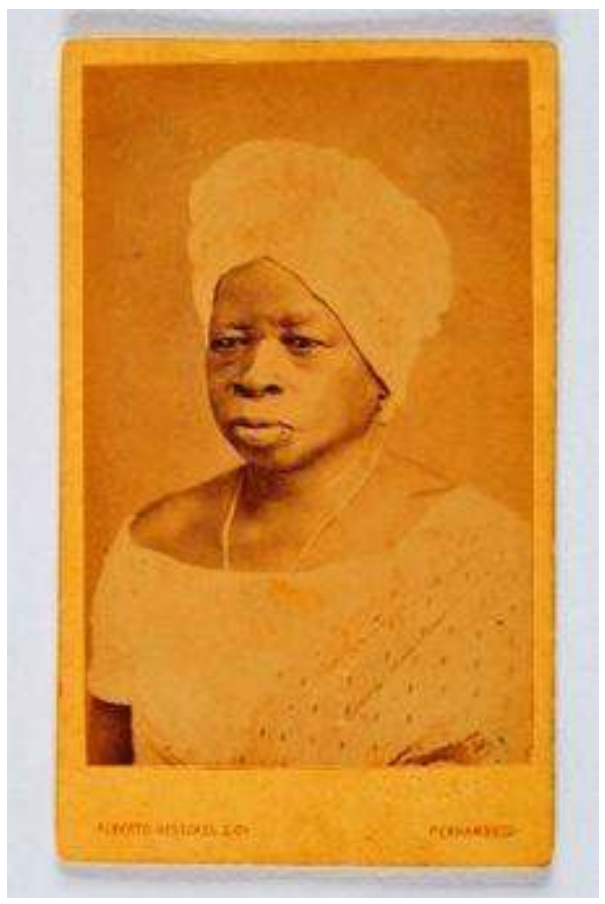

$42 \mathrm{Na}$ sequência da disposição das imagens nas paredes da sala, o terceiro núcleo de inteligibilidade se organizou em torno da técnica de fotopintura, contemplando, assim, o princípio curatorial de valorizar aspectos da técnica fotográfica estimados pelo colecionador. No texto expositivo a noção de técnica associa-se a elaboração de uma estética singular do retrato fotográfico dos oitocentos:

Eugene Disderi, famoso fotografo francês, inventou o formato carte-de-visite e fez

fama e fortuna que ganhou fama no seu estúdio situado a Rue de Rivoli, em Paris. 
Era também um prolixo defensor da boa estética fotográfica que, resumidamente, significava agradar o cliente de qualquer maneira, por meio de um conjunto de estratégias técnicas próprias ao estúdio oitocentista, dentre elas a fotopintura. A lição de Disderi foi seguida à risca por fotógrafos ao redor do mundo que ofereciam os serviços de fotopintura, uma modalidade de retrato fotográfico que era embelezado por meio de recursos da pintura, geralmente guache para o papel e óleo, quando a ampliação era feita em tela. A fotopintura foi, também, uma forma de dar um ar aristocrático, à maneira do retrato pintado, as fotografias que se multiplicavam e se popularizavam

\section{Retrato Feminino, sem autoria, s/d}

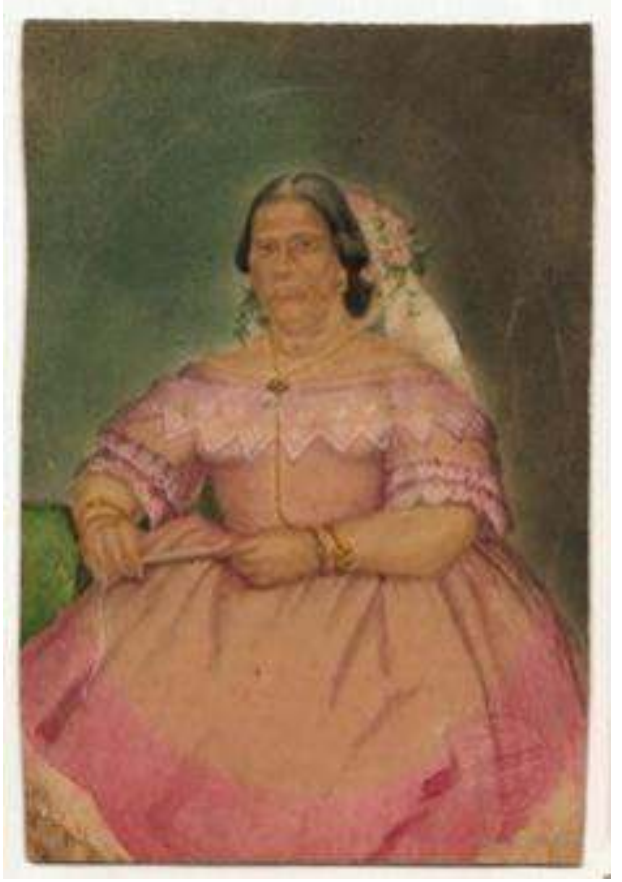


10. Retrato Mãe e filha, $P E, A$. Ducasble

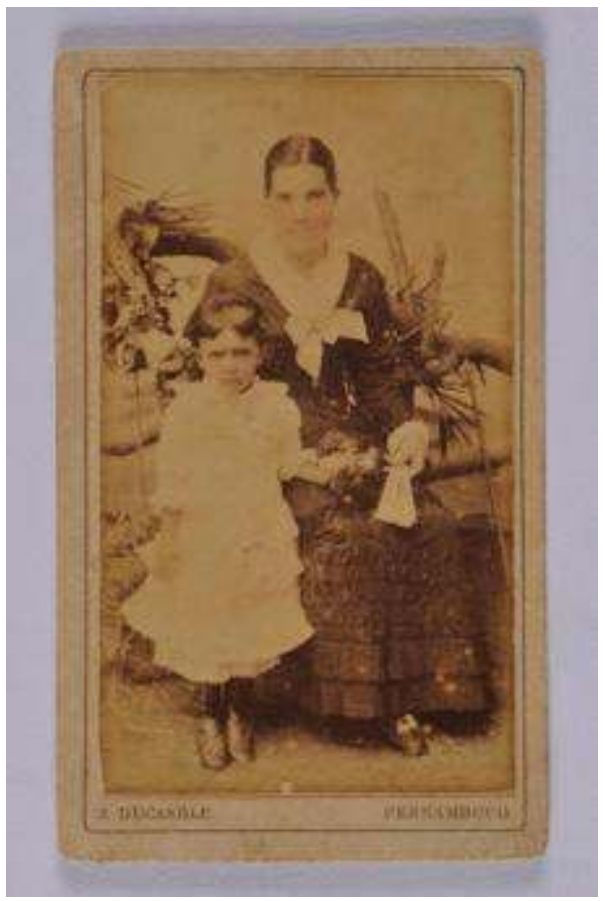

43 A concepção da fotografia como suporte de relações sociais foi contemplada pelo quarto núcleo de inteligibilidade que se referiu a base social da qual essas imagens são referência incontornável - a escravidão. $O$ texto de apoio ampara a narrativa proposta pelo conjunto de imagens:

Os retratos revelam a sua profunda inserção no cotidiano da vida brasileira dos africanos e de seus descendentes, ao mesmo tempo em que coloca face a face dois universos sociais em conflito: o mundo branco dos patrões e o mundo negro dos escravos e africanos libertos. Os sentimentos de familiaridade denotado pela proximidade dos corpos, pela convivência em espaços comuns e pela presença de pessoas negras associadas ao mundo do trabalho, nos fazem pensar como tais relações sociais deixaram marcas profundas na sociedade brasileira. Em sua maioria, são imagens desconcertantes e nada inocentes de um mundo marcado pelo peso discricionário da escravidão. 
11. Ama de Leite, c. 1880, PE, Eugenio e Mauricio Phot

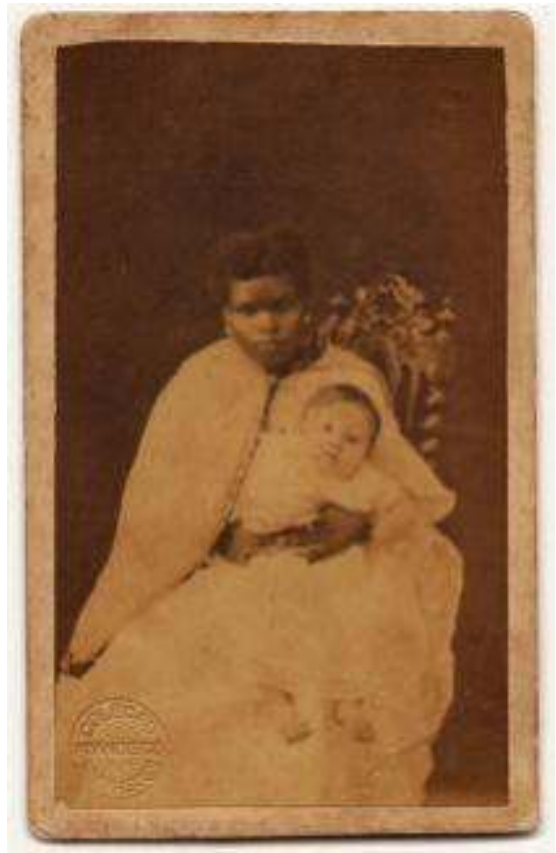

12. Ama de Leite, c. 1890, PE, F. Villela

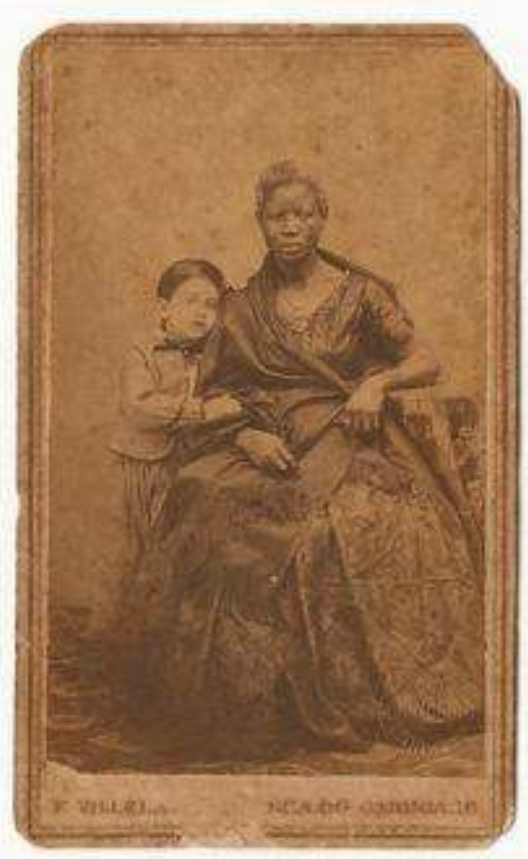


13. Ama de Leite, c. 1890 , autoria não identificada

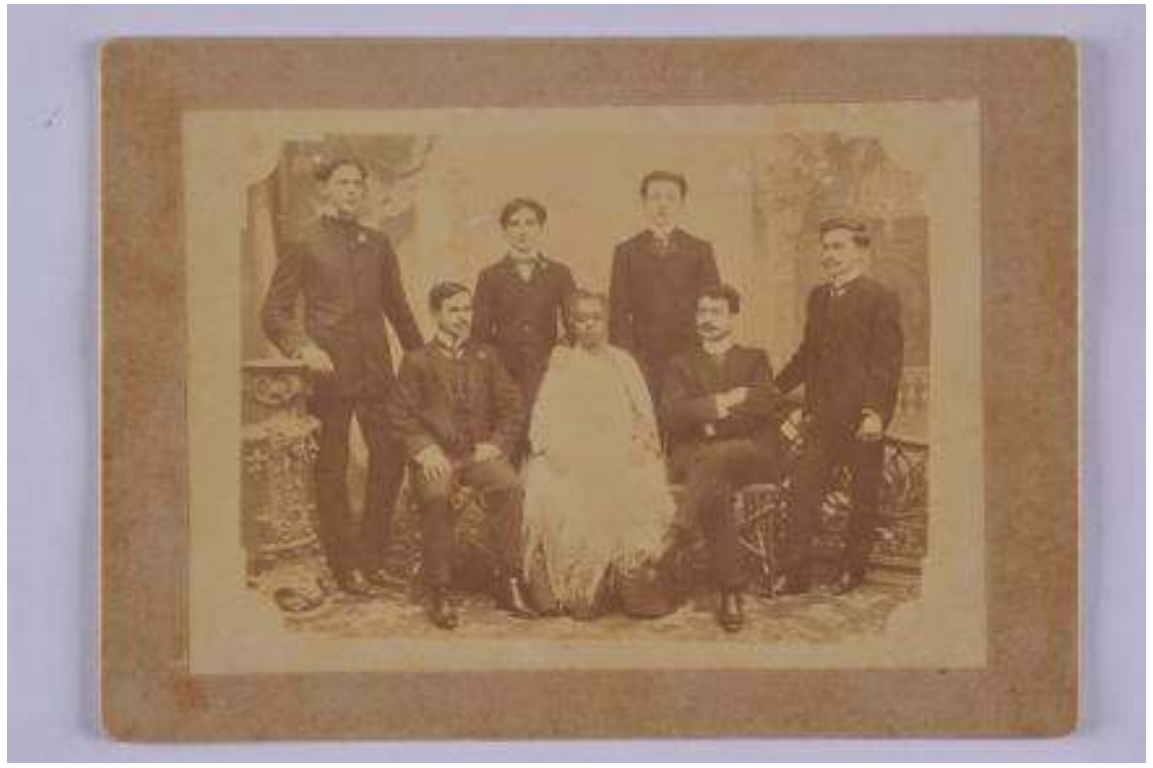

$44 \mathrm{Na}$ parede contígua às imagens sobre a escravidão dispomos o quinto núcleo de inteligibilidade organizado em torno das noções de família e geração - ou idades da vida. No texto a ideia foi apresentada:

As fotografias, na medida em que podem representar as idades da vida e as formas de figurar o núcleo familiar são suportes maiores da memória social. Pelo álbum de família se acompanha o desenvolvimento das crianças, sua transformação em jovens e a entrada no mundo adulto, para então reproduzirem o ciclo da vida casando-se e constituindo famílias. Para cada idade se constrói um atributo de figuração, para cada momento uma pose, para cada composição uma forma de narrar. Cachorrinhos com seus donos, gatinhos como membro da família, dividiam o espaço da 'ternura fotográfica' com bebês rechonchudos cercados de adereços de maciez e conforto. 
14. Retrato infantil, c. 1890, PE, Oliveira \& Fondella

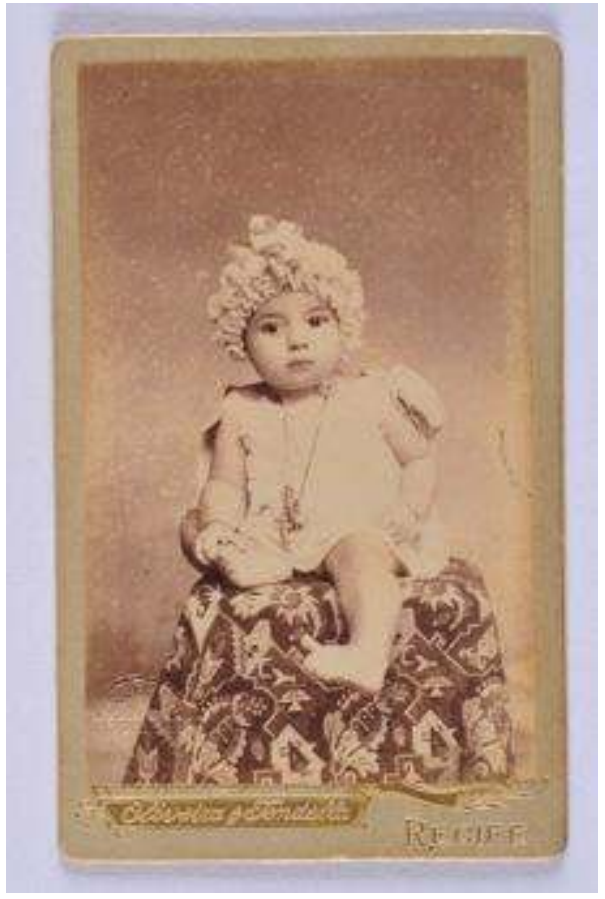

15. Retrato Família, c. 1890, PE, Louis Piereck

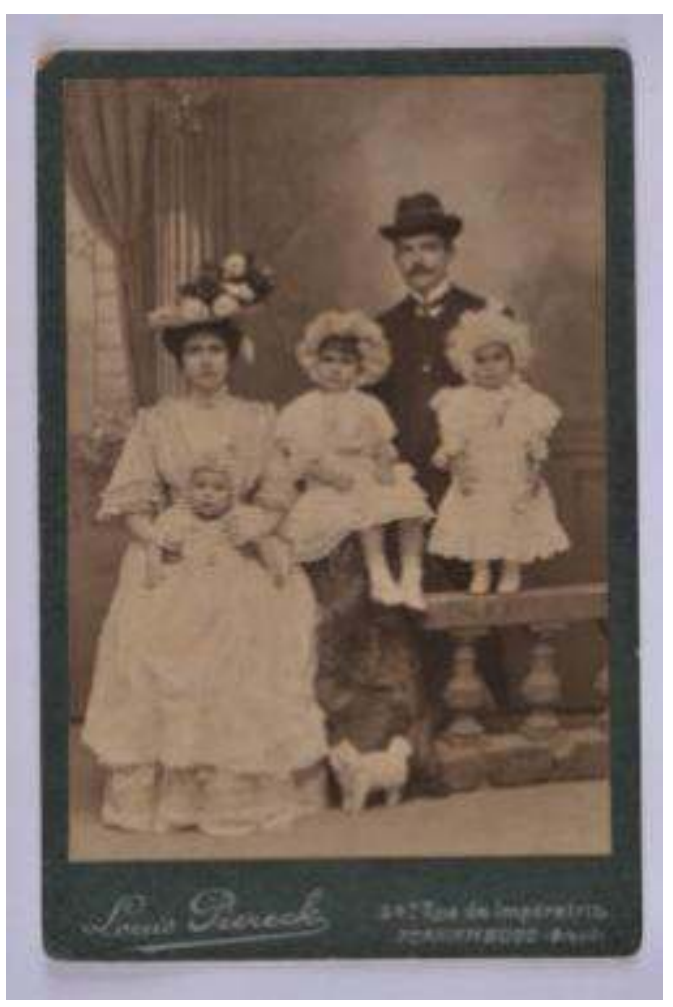


15. Retrato Grupo Feminino, c. 1870, autoria não identificada

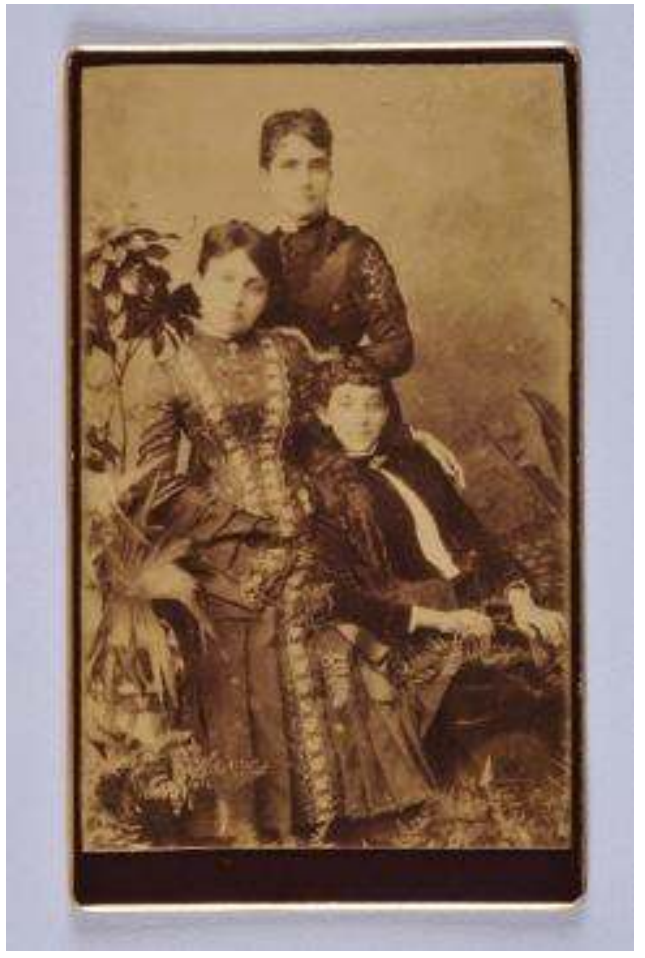

16. Retrato infantil, c. 1870, PE, Flosculo Magalhães

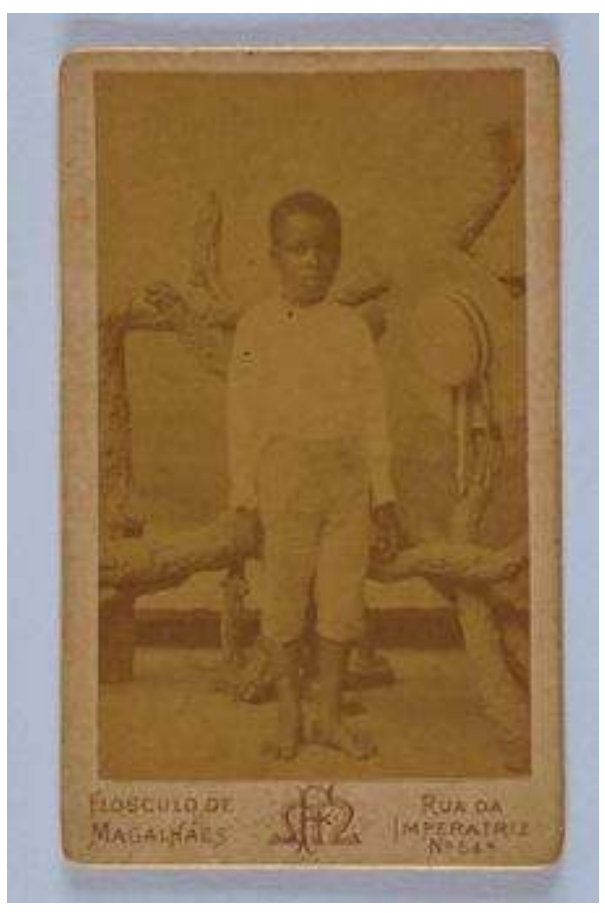

45 O sexto núcleo valorizou os versos das fotografias, por nele estarem contidos importantes informações sobre o circuito social da fotografia da qual as imagens colecionadas por Francisco Rodrigues foram tributárias:

Os versos dos retratos compõem uma coleção à parte. Por meio deles podemos obter informações preciosas sobre os circuitos sociais da imagem fotográfica entre $1840 \mathrm{e}$ 1920. Identificamos as viagens dos abastados da época aos lugares distantes por 
meio do verso de uma imagem escrito em japonês ou alemão; conhecemos os processos e serviços fornecidos pelos fotógrafos, bem como o seu reconhecimento social atribuído pelas honras e medalhas ganhas em exposições, ou pelo prestigioso título de Fotógrafo da Casa Imperial ; nos inteiramos do cosmopolitismo deste tipo de produto através da indicação das várias filias de uma casa fotográfica, que podiam mesmo compor um circuito internacional: Rio-Paris- Recife. A rica composição gráfica permite acompanhar as mudanças na forma de grafar tipos, decorar informações simples e ainda anunciar o serviço prestado, uma fonte inestimável para o estudo do design gráfico da época.
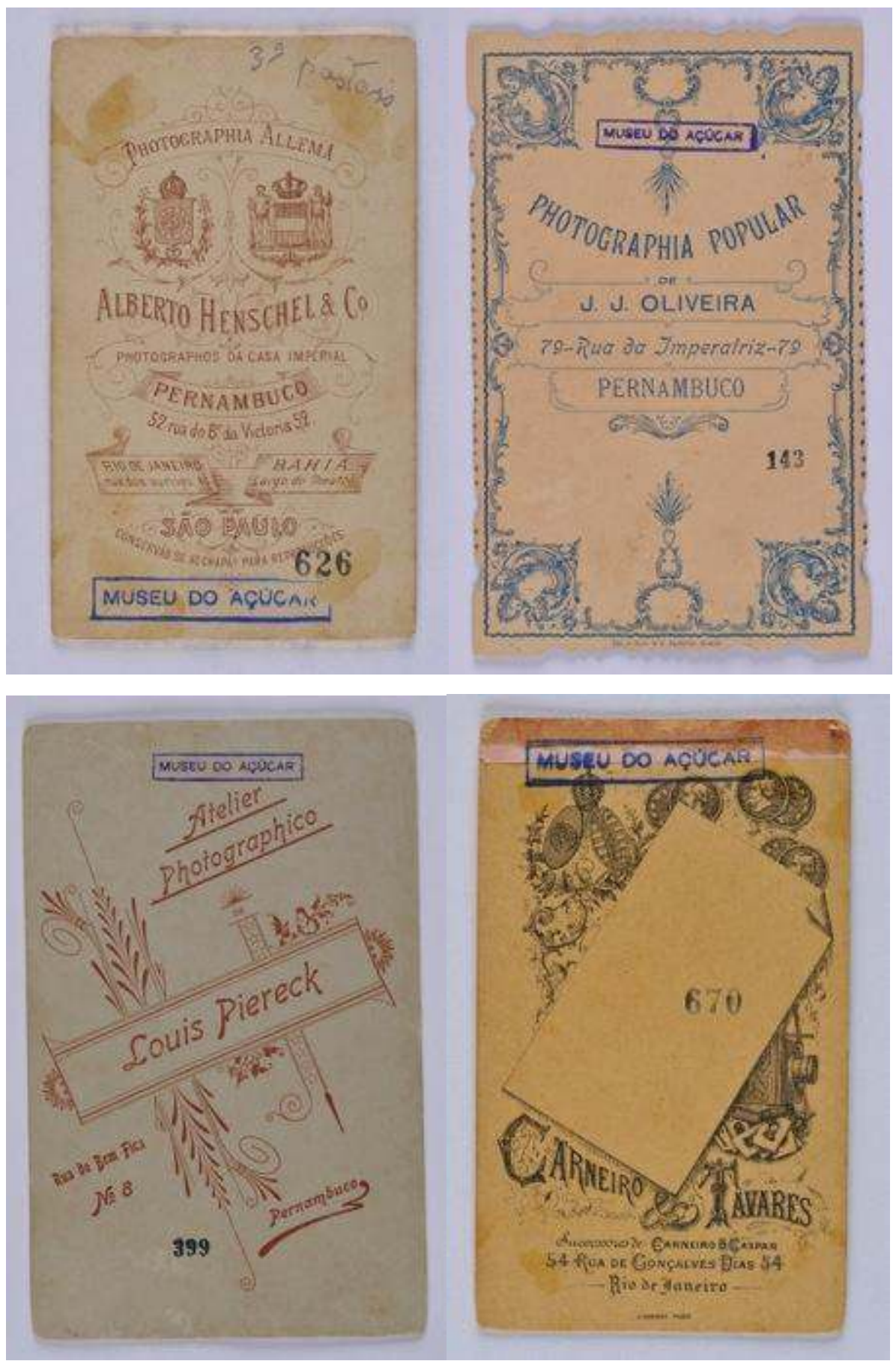

Por fim, no espaço contíguo à grande sala em que expusemos os seis núcleos de inteligibilidade da mostra, foi montado um gabinete de Objetos preciosos: Daguerreótipos, Ambrótipos, Ferrótipos e Talbótipo. Nesse espaço, totalmente pintado de cor púrpura, 
foram dispostas vitrines com as diferentes modalidades de objetos. Nesses objetos, as imagens se revelavam nos principais processos de fixação em suporte material tecidos, ferro, laca, vidro esmaltado - incluindo-se um talbótico - uma raridade nas coleções fotográficas brasileiras. Nos textos que orientavam o percurso do visitante pela sala busquei ampliar o universo de informações para valorizar o que estava sendo exposto:

O primeiro daguerreotipo produzido no Brasil foi feito pelo Abade Compte, na atual Praça XV, no Rio de Janeiro, no dia 17 de janeiro de 1840conforme foi anunciado com grande entusiasmo pelo Jornal do Comércio,. Entrou para as graças do jovem D. Pedro, que seis meses mais tarde seria consagrado Imperador do Brasil, tornando-se um grande incentivador da prática fotográfica. O daguerreótipo ganhou ares imperais e passou a dividir, com as outras modalidades semelhantes de registro da luz, o espaço por excelência da imagem e auto imagem do Império Brasileiro.

Sob o império do retrato grupos sociais se distinguiam, construindo através de marcas visuais a sua identidade social. 0 retratado, escolhendo a pose adequada para a mise-en-scène do estúdio fotográfico, evidenciava a adoção de um determinado estilo de vida e padrão de socialidade. Os objetos e trejeitos adotados para criar a ambientação ilusória do estúdio atuavam como emblemas de pertencimento social e, segundo os códigos de comportamento, como indicativos de pertencimento ao grupo social detentor dos meios técnicos de produção cultural ou do acesso a estes.

A presença de um conjunto variado de modalidades de retrato dentro do padrão de objeto único, como eram esses processos do século XIX aqui expostos, aponta para a riqueza e opulência da sociedade pernambucana do oitocentos, que acompanhava as tendências internacionais de consumo fotográfico e projetava, para o cenário nação que se constituída, a imagem da sociedade nordestina como o retrato marcante de um certo Brasil.

Exposição, fotos Melanie Guerra, 2011

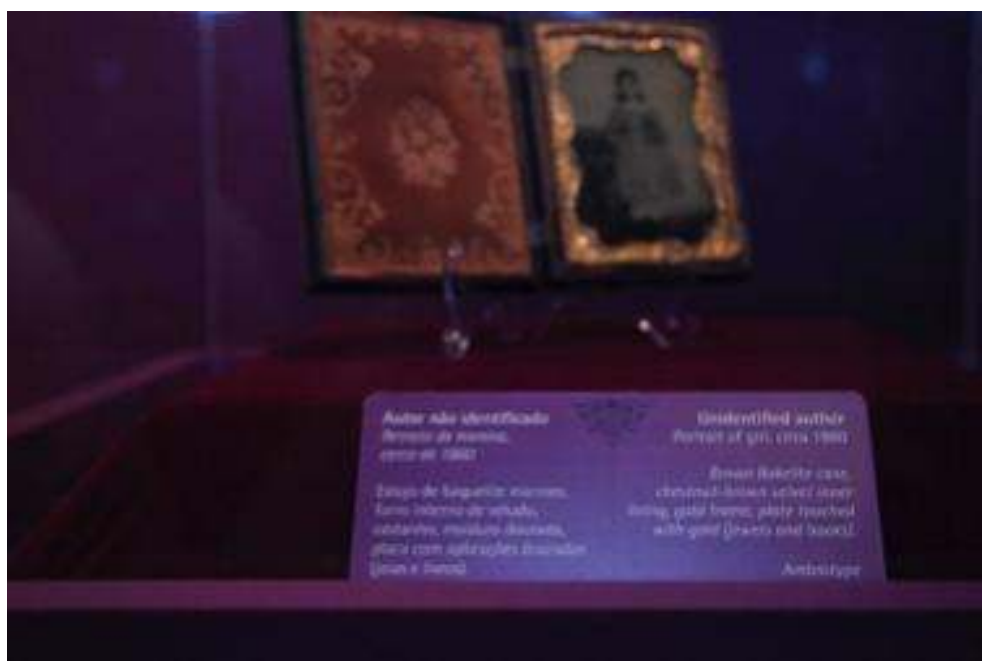


Exposição, fotos Melanie Guerra, 2011

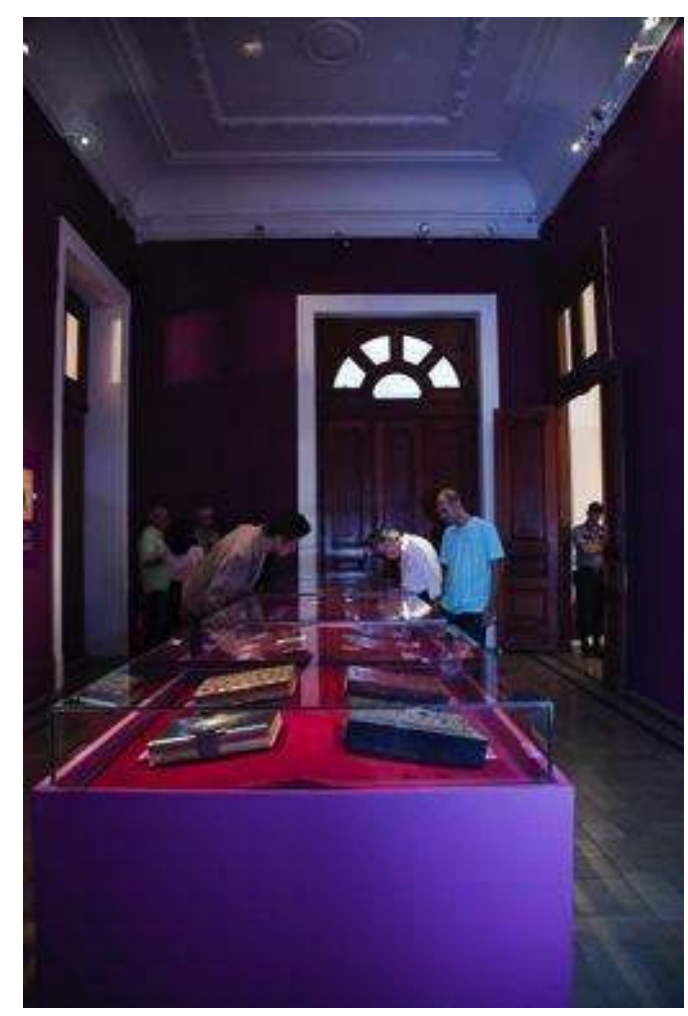

\section{Conclusão}

Creio que a forma de disposição do texto escrito e da imagem na curadoria de uma exposição, principalmente, em se tratando de uma exposição fotográfica, deve considerar alguns aspectos dessa relação. Para os fins desse artigo quero destacar sobretudo um aspecto que consideramos relevante para a composição da proposta de curadoria.

Em uma crítica, muito comum, ao uso das imagens fotográficas, condena-se sua utilização meramente ilustrativa. Em minhas pesquisas sobre os usos e funções da fotografia, em vários contextos, em que se devia apresentar a análise das imagens em texto expositivo, ficou claro que a imagem quando ilustra adequadamente o texto escrito, opera como um amplificador. Nesse caso a imagem reverbera visualmente o sentido que texto escrito expressa. A visualização do argumento permite que o leitor perceba e identifique elementos visualmente significativos, que não são redundantes em relação à compreensão textual, mas complementares. Portanto, o uso ilustrativo das imagens faz parte da tradição ocidental que se consolidaria no século XVIII, justamente, com a cultura enciclopédica da Ilustração. 
Exposição, fotos Melanie Guerra, 2011

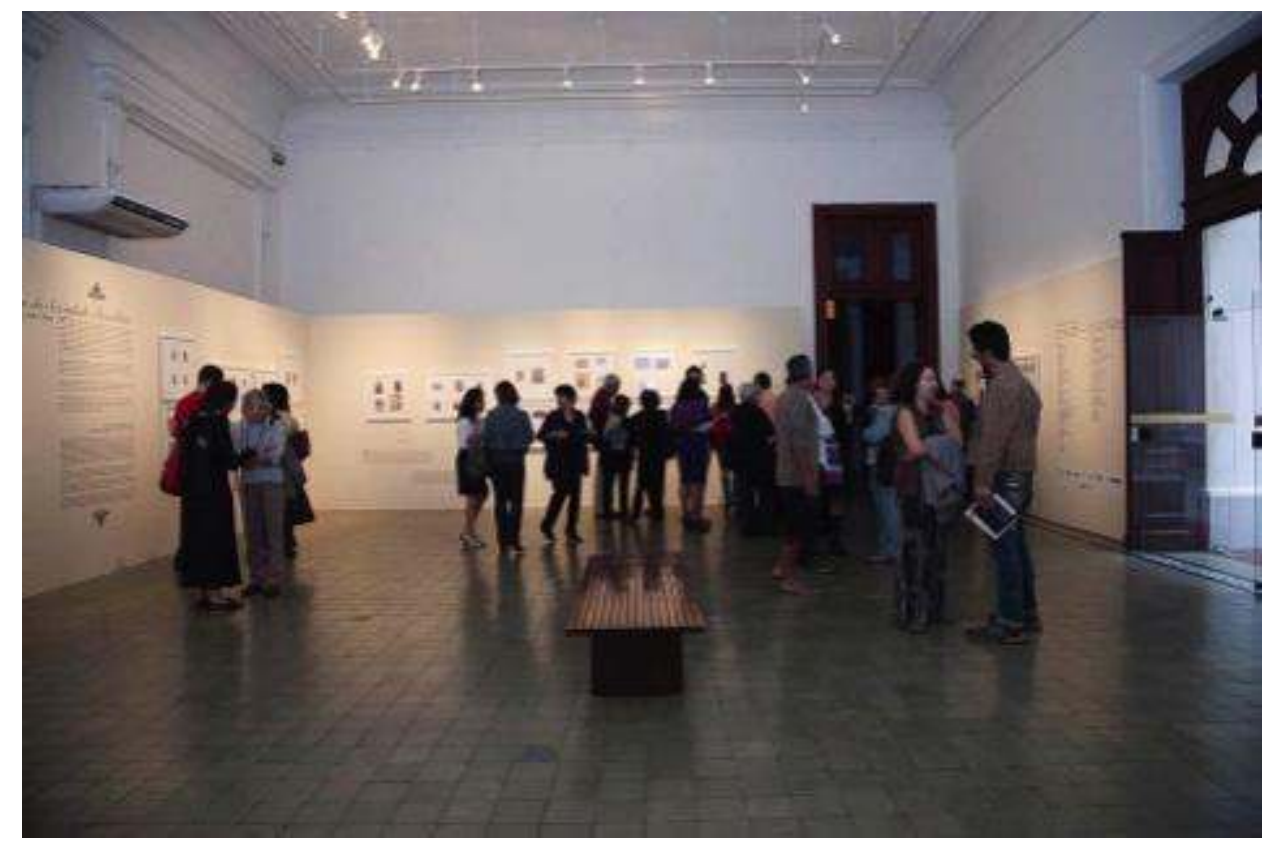

Exposição, fotos Melanie Guerra, 2011

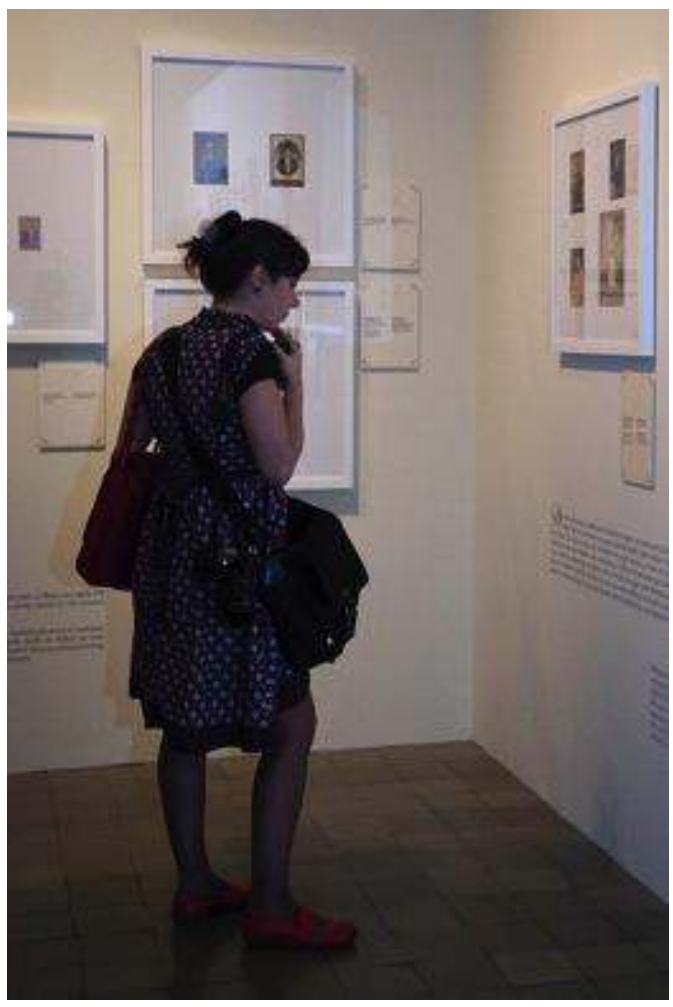


Exposição, fotos Melanie Guerra, 2011

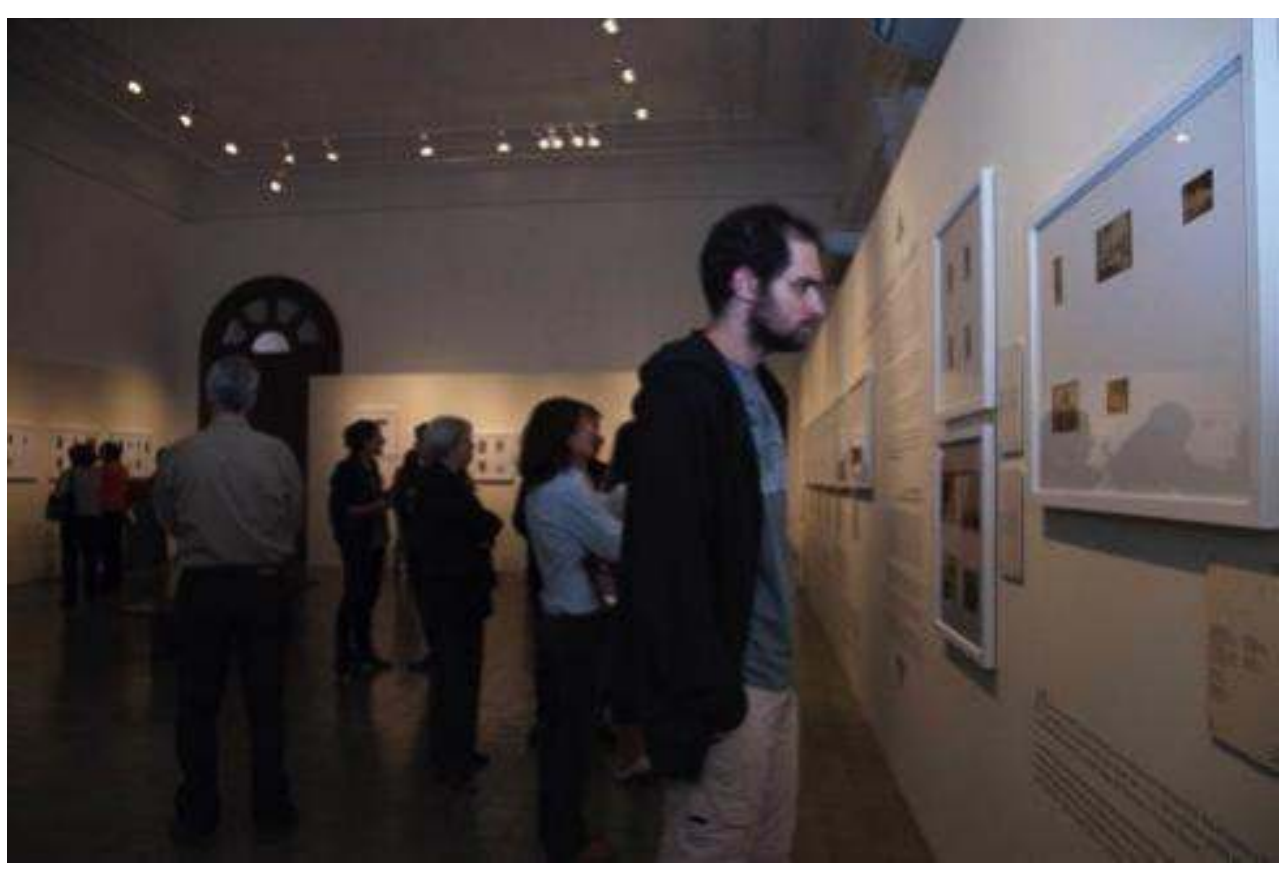

Ao entrar na sala e se deparar, no centro dela, com o título da exposição como uma imagem em destaque, o expectador pode escolher começar pelo sentido do relógio, ou ao contrário. Em ambos os casos, sua escolha se ampararia na leitura dos textos que, ao final do percurso, lhe possibilitaria uma compreensão do passado que seria a síntese de palavras e imagens. Nos quadros de uma exposição, sobretudo as de sentido histórico, texto e imagem devem, portanto, servir de mapa cognitivo aos possíveis percursos do olhar do público expectador.

\section{BIBLIOGRAFIA}

BACZKo Bronislaw, "Imaginação social", in Enciclopédia Einaudi, s. 1, Lisboa, Imprensa Nacional/ Casa da Moeda, Editora Portuguesa, 1985.

BORGES Jorge Luis, "Funes, o memorioso", in Prosa Completa, Barcelona, Ed. Bruguera, 1979, vol. 1., p. $477-484$

BRUCE Fabiana, Caminhando numa cidade de luz e sombras: a fotografia moderna no Recife na década de 1950, Recife, Editora Massangana/Fundação Joaquim Nabuco, 2013.

CALLEGARI B.; BUOSI R (org.), Fotolabor, a fotografia de Werner Haberkorn, São Paulo, Espaço Liquido Editora, 2014.

CANABARRo I. S., Dimensões da cultura fotográfica no Sul do Brasil, Coleção Museu Antropológico Diretor Pestana, Ijuí, RS: UNIJUI, 2011. 
costa Helouise \& SILVA Renato R., A fotografia moderna no Brasil, São Paulo, Cosac Naif, 2004 [1a edição de 1985]

Fabris Annateresa, Fotografia e arredores, Florianópolis, Letras contemporâneas, 2009.

GREGORY Lucia Teresinha Macena, Retratos, Instantâneos e lembranças: a trajetória e o acervo da fotógrafa Írica Kaefer, Marechal Rondon (1954-1990), Niterói, PPGH-UFF, Tese de Doutorado em História, 2010.

Lissovsky Mauricio, “Guia prático das fotografias sem pressa”, in Retratos Modernos, Claudia Beatriz HEYNEMANN; Maria DO CARMO TEIXEIRA RAINHO, Rio de Janeiro, Arquivo Nacional, 2005.

Lissovsky Mauricio, Refúgio do Olhar: a fotografia de Kurt Klagsbrunn no Brasil dos anos 1940, Rio de Janeiro, Casa da Palavra, 2013.

LOPES Marcos Felipe Brum, Mario Baldi - Fotografias e narrativas da alteridade na primeira metade do século XX, Niterói, PPGH-UFF, Tese de Doutorado em História, 2014.

LOUZADA Silvana, Prata da Casa: fotógrafos e a fotografia no Rio de Janeiro, Niterói, Eduff, 2013.

MAUAD Ana M., "Fotografia pública e cultura do visual, em perspectiva histórica", in Revista Brasileira de História da Mídia, v. vol.2, p. 11-20, 2013

MELlo Maria Teresa Bandeira de., Arte e Fotografia: o movimento pictorialista no Brasil, Rio de Janeiro, Funarte, 1998

MENEZES Lucas Mendes, Entre apertadores de botão e aficionados - prática fotográfica amadora em Belo Horizonte (1951-1966), Niterói, PPGH-UFF, Dissertação de Mestrado em História, 2013.

O Retrato Brasileiro: Fotografias da Coleção Francisco Rodrigues 1840-1820, Rio de Janeiro, FUNARTE/ Núcleo de Fotografia ; Fundação Joaquim Nabuco/Departamento de Iconografia, 1983

RAINHO Maria do Carmo Teixeira, Moda e Revolução nos anos 1960, Rio de Janeiro, Contra Capa, 2014.

TESSARI Anthony Beux, Imagens do labor: memória e esquecimento nas fotografias do trabalho da antiga Metalúrgica Abramo Eberle (1896-1940), Porto Alegre, 2013. Dissertação (Mestrado em História) - FFCH, PUCRS. Disponível em. Acesso em agosto 2013.

\section{NOTAS}

1. Refiro-me principalmente ao título da obra clássica Cultura e Opulência do Brasil por sua Drogas e Minas, do Jesuíta João Antônio Andreoni foi publicado em 1711. Cultura e Opulência, obra dividida em quatro partes, dedica a sua primeira parte ao estudo da - Cultura e Opulência do Brasil na lavra do açúcar - Engenho Real corrente e moente. Tomo a idéia como um princípio norteador da riqueza gerada pelo trabalho agrícola e da sociedade que se organiza com base na mão de obra escrava, cujo domínio de homens por outros homens definiram o fundamento de um princípio civilizador, excludente por origem.

2. Remeto aqui a noção de antiquário, do movimento antiquarista do século XVII. Este caracteriza-se pel a consolidação de uma história erudita que se define por quatro aspectos fundamentais : 1 . culto das peças originais, cartas, decretos reais, bulas pontifícias, assim como o dos selos e brasões, ligados uns e outros à obsessão e de esclarecer a origem dos poderes e das intituições. 2. publicação de instrumentos de trabalhos adaptados, para a plena interpretação dos documentos acima referidos ; 3. definição da operação histórica como sendo um trabalho sobre 
textos, inspirando-se nos trabalhos de gramática e de exegese 4. objetivo máximo da história erudita : edificar uma cronologia exata pelo confronto sistemático dos testemunhos.

\section{RESUMOS}

O artigo reflete sobre a organização de uma exposição fotográfica, no âmbito do FotoRio 2011, com imagens da coleção Francisco Rodrigues, depositada no Centro de Documentação e de Estudos Históricos, da Fundação Joaquim Nabuco. Avalia aspectos da proposta de curadoria e destaca a importância da coleção para o estudo da história das imagens no Brasil. Concentra-se na análise da modalidade retrato fotográfico como fio condutor para a compreensão dos usos e funções da fotografia no Brasil do século XIX.

L'article offre une réflexion sur une exposition photographique réalisée dans le cadre de FotoRio 2011, composée d'images de la collection Francisco Rodrigues, du Centre de Documentation et d'Etudes Historiques (Centro de Documentação e de Estudos Históricos) de la Fondation Joaquim Nabuco. L'article analyse divers aspects de la proposition du commissaire de l'exposition et souligne l'importance de la collection pour les recherches portant sur l'histoire des images au Brésil. Le texte se concentre de façon plus spécifique sur une analyse du portrait photographique comme modalité et fil conducteur permettant la compréhension des usages et fonctions de la photographie au Brésil au XIXème siècle.

\section{ÍNDICE}

Mots-clés: photographie, exposition, portrait, société, Brésil du XIXe siècle

Palavras-chave: fotografia, exposição, retrato, sociedade, Brasil oitocentista

\section{AUTOR}

\section{ANA MARIA MAUAD}

Professora do Departamento de História da UFF

Pesquisadora do CNPq e Cientista do Nosso Estado Faperj (2013-2016)

anammauad[at]uol.com.br 